\title{
The Influence of Tillage and Water Suply on the Soy Production
}

\author{
Violeta SIMIONESCU ${ }^{1,2}$, Monica TANC ${ }^{2}$ Daniela PLESOIANU ${ }^{1}$, Marioara RUSU ${ }^{3}$ \\ ${ }^{1}$ Ovidius University,124 Mamaia Blvd, 900527, Constanta, Romania, \\ ${ }^{2}$ SCDA Valu lui Traian, Calea Dobrogei Str, 460, 907300, Valu lui Traian, Constanta \\ ${ }^{3}$ Institute of Agricultural Economics, Romanian Academy, 13, Calea 13 Septembrie, District 5, \\ Bucharest, Romania, Phone: +400213182411 \\ *corresponding author, e-mail: violetams59@yahoo.com
}

Bulletin UASVM series Agriculture 73(1)/2016

Print ISSN 1843-5246; Electronic ISSN 1843-5386

DOI 10.15835/buasvmcn-agr: 12017

\begin{abstract}
The choice of soil tillage systems adapted to the pedo-climatic conditions and crop requirements so that the yield and economic efficiency should be attractive for farmers, as well as the modernization of agricultural machinery and implements suitable for this system are expected to expand in the future and to contribute thus to the sustainable development of agriculture, to the improvement of soil fertility and environmental protection. The promotion of conservation agriculture system in versions adapted to the soil conditions with mid-heavy texture and to the requirements of the main crops in the south of Romania which should provide competitive productions, both quantitatively and qualitatively, with reduced costs and high profit. The research has been carried out at the Valul lui Traian Station for Agricultutral Research and Development. The experiments were placed according to the method of subdivided plots, in three repetitions, with tillage systems, towards water conservation and economical optimization of the agricultural management and consisted of the following versions: the level of water supply (three graduations); deep loosening of the soil (two graduations); basic tillage (three graduations). Soy reacts well to irrigations, the yield being very significant and ensured statistically. By analyzing the production data obtained as an effect of the interaction between the three factors and given the no irrigation/no chisel plow/ vibromix version, all the versions cultivated in conditions of water supply/chisel plow and no chisel plow have statistically ensured production growth that is significant, distinctly significant and very significant. Soy uses well the water administered in norms of $50 \%$ of the $\mathrm{AHI}$, obtaining higher yields even than those obtained in conditions of irrigation with $100 \%$ of the AHI.
\end{abstract}

Keywords: chisel plow, water, soy, tillage.

\section{INTRODUCTION}

The choice of soil tillage systems adapted to the pedo-climatic conditions and crop requirements so that the yield and economic efficiency should be attractive for farmers, as well as the modernization of agricultural machinery and implements suitable for this system are expected to expand in the future and to contribute thus to the sustainable development of agriculture, to the improvement of soil fertility and environmental protection.

\section{MATERIALS AND METHODS}

The soil in the location perimeter of the experimental lot is vermic chernozem, formed on loess deposits, with medium texture, namely loamy to loamy-earthen, with a clay content between 28 and $32 \%$, distributed homogenously in the soil profile. The soil is light and very light (the degree of subsidence being under 0\%), emphasizing a high risk for degradation by excessive loosening 
on short-term and a high risk for secondary depth compaction on long-term.

The soil permeability to water is high(the numeric values of the hydraulic conductivity being over 20-30 $\mathrm{mm} \cdot \mathrm{h}^{-1}$ ). In the area, groundwater is usually deeper than $10 \mathrm{~m}$. Consequently the natural drainage is good and the risk of excess humidity (at the surface or at depth) is highly reduced.

The structural hydrostability of the soil is reduced, the content of water-stable structural macroaggregates is under 4-8\%, emphasizing thus a high risk of soil degradation by destructuration, especially in the intensely irrigated areas, and particularly at the surface.

The soil supply with nutritive elements is moderate. Thus, in the first 10 and $20 \mathrm{~cm}$, respectively, the humus content was between 3.59 and $3.02 \%$; the content of mobile phosphorus was between 60 and 40 mg.kg-1, total nitrogen was between 0.23 and $0.20 \%$, and potassium was between 180 and 170 mg. $\mathrm{kg}^{-1}$.

The soil reaction was poor to moderately alkaline, the $\mathrm{pH}$ (determined in water) being 8.00 8.02.

The experiments were placed according to the method of subdivided plots, in three repetitions on the field, with tillage systems adapted to the local conditions, oriented towards the protection of the agrophysical state of the soil, towards water conservation and economical optimization of the agricultural management and consisted of the following versions:

\section{A. The level of water supply}

A1 - full-time irrigation $(1 \mathrm{~m})$ on $0-90 \mathrm{~cm}$; A2 - half-time irrigation $(1 / 2 \mathrm{~m})$ on $0-90 \mathrm{~cm}$; A3 - not irrigated.

\section{B. Deep loosening of the soil}

B1 - by chisel plow (work executed at the beginning of the experiments);

B2 - no chisel plow work.

\section{Basic tillage}

C1 - plowing with moldboard plow $20-22 \mathrm{~cm}$;

C2 - plowing with chisel plow $18-20 \mathrm{~cm}$;

C3 - tillage with disk plow $13-15 \mathrm{~cm}$;

The plants cultivated every year by rotation were: maize, soy and wheat.

Fertilization and other specific works for plant protection during the vegetation period, and pest and disease control were applied uniformly for all versions.

In the irrigated plots, one to three waterings were applied uniformly, according to the plant requirements, but also to the technical and economical possibilities.

Observations were accomplished of the evolution of the vegetative phenophases.

The average yield per ha was determined and the productivity elements were analyzed.

Soil samples were collected in order to establish soil humidity.

Also, soil samples were collected in order to establish the effect of tillage on certain physical and chemical soil indicators. Measurements were done regarding the fuel consumption.

\section{RESULTS AND DISCUSSION}

Soy can be cultivated in our country only in conditions of excellent water supply (Alexandru I. Cociu et al, 2011).

By analyzing the production obtained as an effect of each of the studied factors taken separately, we observed the following:

Soy reacts well to irrigations, the yield being very significant and ensured statistically (Tab.1).

The influence of the chisel plow work is poor, the difference between versions being $133 \mathrm{~kg} / \mathrm{ha}$ (Tab. 2).

The influence of tillage is poor, the difference in production between the plowed version and the other two being $-178 \mathrm{~kg} / \mathrm{ha}$ in the chisel and -125 $\mathrm{kg} / \mathrm{ha}$ in the vibromix (Tab. 3).At the interaction

Tab. 1. The soy production obtained as an effect of various water supply regimen, Valul lui Traian, 2008-2010.

\begin{tabular}{cccccc}
\hline \multirow{2}{*}{ Crt .nr. } & The variant & \multicolumn{2}{c}{ Production } & Difference & \multirow{2}{*}{ Semnficant } \\
\cline { 2 - 5 } & $100 \%$ & $\mathrm{Kg} / \mathrm{ha}$ & $\%$ & $\mathrm{Kg} / \mathrm{ha}$ & \\
\hline 1 & $50 \%$ & 2566 & 132 & 631 & $* * *$ \\
\hline 2 & $0 \%$ & 2961 & 153 & 1026 & $* * *$ \\
\hline 3 & 1935 & 100 & $\mathrm{Mt}$ & \\
DL 5\% 4,64 kg/ha DL1\% $7,68 \mathrm{~kg} / \mathrm{ha}$ DL $0,1 \% 14,27 \mathrm{~kg} / \mathrm{ha}$ & &
\end{tabular}


between water supply and chisel plow work, the following versions are distinguished: irrigated $50 \% /$ chisel plow work and irrigated 50\%/no chisel plow work, the differences in production being statistically ensured and very significant (Tab.4)

At the interaction between the water supply levels and tillage, all the tillage versions on water supply at $50 \%$ of the active humidity interval (AHI) (Tab.5) are statistically backed and very significant.

By analyzing the production data obtained as an effect of the interaction between the three factors presented in Table 6 . and given the no irrigation/no chisel plow/vibromix version, all the versions cultivated in conditions of water supply/ chisel plow and no chisel plow have statistically ensured production growth that is significant, distinctly significant and very significant (Tab.6).

Table 6. also emphasizes the idea that soy uses better the water supplied by irrigation at $50 \%$ of the AHI, whether the chisel plow is used or not, and with all tillage accomplished. Thus, the highest yield is obtained in the versions irrigated with $50 \%$ of the AHI (Felicia Cchetan et a 2014I).

\section{CONCLUSION}

The soy crop is demanding in terms of water. The analysis of the results obtained leads to the following conclusions:

Soy uses well the water administered in norms of $50 \%$ of the AHI, obtaining higher yields even than those obtained in conditions of irrigation with $100 \%$ of the AHI.

Tab.2. Soy production under the influence of tillage (chisel plow work),Valul lui Traian, 2008-2010

\begin{tabular}{|c|c|c|c|c|c|}
\hline \multirow{2}{*}{ Crt.nr. } & \multirow{2}{*}{ The variant } & \multicolumn{2}{|c|}{ Production } & \multirow{2}{*}{$\begin{array}{c}\text { Difference } \\
\mathrm{Kg} / \mathrm{ha}\end{array}$} & \multirow{2}{*}{ Semnficant } \\
\hline & & $\mathrm{Kg} / \mathrm{ha}$ & $\%$ & & \\
\hline 1 & Scarificat & 2554 & 100 & Mt & \\
\hline 2 & Nescarificat & 2421 & 94 & -133 & \\
\hline
\end{tabular}

Tab. 3. Soy production under the influence of tillage and chisel plow work permanence, Valul lui Traian, 2008-2010

\begin{tabular}{cccccc}
\hline \multirow{2}{*}{ Crt.nr. } & \multirow{2}{*}{ The variant } & \multicolumn{2}{c}{ Production } & Difference & \multirow{2}{*}{ Semnficant } \\
\cline { 3 - 5 } & Arat & $\mathrm{Kg} / \mathrm{ha}$ & $\%$ & $\mathrm{Kg} / \mathrm{ha}$ & \\
\hline 1 & Cizel & 2588 & 100 & $\mathrm{Mt}$ & $\mathrm{Mt}$ \\
\hline 2 & 2410 & 93 & -178 & 000 \\
\hline 3 & Vibromixt & 2463 & 95 & -125 & 000 \\
\hline DL 5\% 2,01 kg/ha & DL1\% 2,74 kg/ha DL $0,1 \% 3,67 \mathrm{~kg} / \mathrm{ha}$ & & &
\end{tabular}

Tab. 4. Soy production obtained as an effect of the interaction between water supply and chisel plow work, Valul lui Traian, 2008-2010

\begin{tabular}{ccccccc}
\hline \multirow{2}{*}{ Crt.nr. } & \multicolumn{2}{c}{ The variant } & \multicolumn{2}{c}{ Production } & Difference & \multirow{2}{*}{ Semnficant } \\
\cline { 2 - 6 } & Irigat & Scarif./Nscr. & Kg/ha & $\%$ & $\mathrm{Kg} / \mathrm{ha}$ & \\
\hline 1 & $100 \%$ & Scarif. & 2560 & 100 & $\mathrm{Mt}$ & Mt \\
\hline 2 & $100 \%$ & Nescarf. & 2493 & 97 & -67 & 000 \\
\hline 3 & $50 \%$ & Scarif. & 2757 & 107 & 197 & $* * *$ \\
\hline 4 & $50 \%$ & Nescarf. & 2691 & 105 & 131 & $* * *$ \\
\hline 5 & $0 \%$ & Scarif. & 2244 & 87 & -316 & 000 \\
\hline 6 & $0 \%$ & Nescarf. & 2178 & 85 & -382 & 000 \\
\hline DL 5\% 5,95 kg/ha DL1\% 9,01 kg/ha DL 0,1\% 14,48 kg/ha & & &
\end{tabular}


Tab. 5. Soy production under the influence of the interaction between tillage and irrigation, Valul lui Traian, 2008-2010

\begin{tabular}{ccccccc}
\hline \multirow{2}{*}{ Crt .nr. } & \multicolumn{2}{c}{ The variant } & \multicolumn{2}{c}{ Production } & Difference & \multirow{2}{*}{ Semnficant } \\
\cline { 2 - 6 } & Lucr.sol & Irigat & Kg/ha & $\%$ & Kg/ha & Mt \\
\hline 1 & A & $100 \%$ & 2728 & 100 & Mt & 000 \\
\hline 2 & C & $100 \%$ & 2418 & 88 & -310 & 000 \\
\hline 3 & VB & $100 \%$ & 2552 & 93 & -176 & $* * *$ \\
\hline 4 & A & $50 \%$ & 2983 & 107 & 225 & $* * *$ \\
\hline 5 & C & $50 \%$ & 2920 & 107 & 192 & $* * *$ \\
\hline 6 & VB & $50 \%$ & 2978 & 109 & 250 & 000 \\
\hline 7 & A & $0 \%$ & 2053 & 75 & -675 & 000 \\
\hline 8 & C & $0 \%$ & 1892 & 69 & -836 & 000 \\
\hline 9 & VB & $0 \%$ & 1860 & 68 & -869 &
\end{tabular}

Tab. 6. Soy production obtained as an effect of tillage and different water supply regimen, with the use of the chisel plow

\begin{tabular}{|c|c|c|c|c|c|c|c|c|c|}
\hline \multirow{2}{*}{ Crt.nr. } & \multicolumn{3}{|c|}{ The variant } & \multicolumn{2}{|c|}{ Production } & \multicolumn{2}{|c|}{ Difference } & \multirow{2}{*}{\multicolumn{2}{|c|}{ Semnficant }} \\
\hline & Irigat & Scarif./Nscr & Soil wock & $\mathrm{Kg} / \mathrm{ha}$ & $\%$ & $\mathrm{Kg} / \mathrm{ha}$ & $\mathrm{Kg} / \mathrm{ha}$ & & \\
\hline 1 & $100 \%$ & Scarif. & $\mathrm{A}$ & 2866 & 182 & 1294 & 1095 & $* * *$ & $* * *$ \\
\hline 2 & $100 \%$ & Scarif. & $\mathrm{C}$ & 2385 & 151 & 813 & 614 & $* *$ & $*$ \\
\hline 3 & $100 \%$ & Scarif. & VB & 2329 & 148 & 757 & 558 & $* *$ & $*$ \\
\hline 4 & $100 \%$ & Nescarf. & $\mathrm{A}$ & 2591 & 164 & 1019 & 820 & $* * *$ & $* *$ \\
\hline 5 & $100 \%$ & Nescarf. & $\mathrm{C}$ & 2451 & 155 & 879 & 680 & $* *$ & $* *$ \\
\hline 6 & $100 \%$ & Nescarf. & VB & 2774 & 176 & 1202 & 1003 & $* * *$ & $* * *$ \\
\hline 7 & $50 \%$ & Scarif. & $\mathrm{A}$ & 2740 & 174 & 1168 & 969 & $* * *$ & $* * *$ \\
\hline 8 & $50 \%$ & Scarif. & $\mathrm{C}$ & 2899 & 184 & 1327 & 1128 & $* * *$ & $* * *$ \\
\hline 9 & $50 \%$ & Scarif. & VB & 3101 & 197 & 1529 & 1330 & $* * *$ & $* * *$ \\
\hline 10 & $50 \%$ & Nescarf. & $\mathrm{A}$ & 3226 & 205 & 1654 & 1455 & $* * *$ & $* * *$ \\
\hline 11 & $50 \%$ & Nescarf. & $\mathrm{C}$ & 2942 & 187 & 1370 & 1171 & $* * *$ & $* * *$ \\
\hline 12 & $50 \%$ & Nescarf. & VB & 2856 & 181 & 1284 & 1085 & $* * *$ & $* * *$ \\
\hline 13 & $0 \%$ & Scarif. & $\mathrm{A}$ & 2335 & 148 & 763 & 564 & $* *$ & $*$ \\
\hline 14 & $0 \%$ & Scarif. & $\mathrm{C}$ & 2181 & 138 & 609 & 410 & $*$ & $*$ \\
\hline 15 & $0 \%$ & Scarif. & VB & 2148 & 136 & 576 & 377 & $*$ & \\
\hline 16 & $0 \%$ & Nescarf. & $\mathrm{A}$ & 1771 & 112 & 199 & $\mathrm{Mt}$ & & \\
\hline 17 & $0 \%$ & Nescarf. & C & 1603 & 101 & 31 & 168 & & \\
\hline 18 & $0 \%$ & Nescarf. & VB & 1572 & 100 & Mt & 199 & & \\
\hline
\end{tabular}

In regards to tillage, the production obtained was not very different from one version to the other.

Even though the productions were similar, the technological expenses made the difference as the irrigated crops had the greatest ratio.
The tillage system using the chisel and the vibromix can be the alternative to tillage by plowing in the pedoclimatic conditions of Dobrudja, providing a better preservation of the physical, chemical and humidity properties of the soil. 


\section{REFERENCES}

1. Felicia Chetan., Rusu T., Chetan C.,Simon A., Ignea M.,Deac V.,(2014) Production result obtained from soybean, durind 2007-2012 under the minimum tillage system, at ARDS Turda, I.N.C.D.A. Fundulea Annals, Vol. LXXXII, 215-226,Electronic (Online) ISSN 2067-7758
2. Cociu Alexandru I., Eliana Alionte, Soil Tillage effects on quality of grain in maize, soybean and winter wheat, and their characteristics, under irrigation conditions an I.N.C.D.A. Fundulea, VOL. LXXIX, nr. 2, 2011 Electronic (Online) ISSN 2067-7758, AGROTEHNICA CULTURILOR, www.incda-fundulea.ro 